\title{
MANAGING THE COVID-19 LIFE: A STUDY ON THE IMPACT OF THE PANDEMIC ON ATHLETES WITH INTELLECTUAL AND DEVELOPMENTAL DISABILITIES (IDD) IN WEST BENGAL
}

\author{
Arhita Biswas ${ }^{1}$, Dishari Pal2 ${ }^{2}$ Shuvojit Moulik ${ }^{3 *}$
}

${ }^{1}$ Phd Scholar, Sociology Department, Presidency University, Kolkata, West Bengal. ${ }^{2}$ Intern, Civilian Welfare Foundation Kolkata, West Bengal. ${ }^{3}$ President, Civilian Welfare Foundation.*Corresponding Author’s Email: shuvojitmoulik@gmail.com

\begin{abstract}
The Covid-19 pandemic has had a ripple effect on all our lives, changing our work, leisure, sleeping patterns, food habits and everyday lives. Persons with disabilities, especially those with Intellectual and Developmental Disabilities (IDD), have borne the biggest brunt of the pandemic, being marginalised and side-lined in aspects of medical treatment, accessibility to public facilities and services, and support systems. This paper focuses on the impact of the pandemic on the lives of child athletes with IDD in West Bengal. The study uses primary data collected from guardians of children with IDD using interviews, along with data from other empirical research. The routines of child athletes with IDD have broken down, and have resulted in them undergoing multifarious behavioural and emotional changes. Apart from finding it difficult to cope with the changing situation, the children are also facing problems in accessing medical facilities and services, educational institutions, and open spaces. The legal frameworks for maintaining the health of PWDs are not being followed, causing deterioration and breakdown in communication, transportation, accessibility to services and schemes. Finally, the paper ends with suggestions and measures that must be taken to enable the PWD population to maintain a life of dignity and well-being.

It looks at the changes in behavioral patterns, sleep patterns, and the changes in the daily routines of these athletes. It further looks into the ways these athletes have used mechanisms of sports and exercise to create new sets of routine in making sense of the pandemic life. Accessibility to healthcare facilities and services during this period has also been analysed, and the multifarious problems it holds for persons with disabilities. Legal frameworks at both international and national levels, along with new guidelines for care of PWDs, and the overall Government response in the pandemic have also been studied. Finally, the paper ends with suggestions and measures that must be taken to enable the PWD population to maintain a life of dignity and well-being.
\end{abstract}

Keywords: Disability, Intellectual Disabilities, sports, Covid 19, Pandemic, Lockdown.

\section{INTRODUCTION}

Intellectual and Developmental Disabilities (IDD) usually develops at birth. Such disabilities tend to negatively affect and deteriorate an individual's intellectual, physical and emotional development. Intellectual disability includes problems in intellectual functioning such as the ability to learn, solve, reason and other skills, and adaptive behaviour such as learning conceptual, practical and social skills. IDD affects multiple body parts and systems such as the nervous system, sensory system and metabolism, leading to multiple physical disabilities as well $(1,2)$. American Association of Intellectual and Developmental Disabilities defines intellectual disability as "a disability characterized by significant limitations in both intellectual functioning and in adaptive behavior, which covers many everyday social and practical skills. This disability originates before the age of 18" (1).

(CThe Author(s) 2021. Published by Iquz Galaxy Publisher, India.. This is an Open Access article distributed under the terms of the Creative Commons Attribution CC BY license (http://creativecommons.org/licenses/by/4.0/), which permits unrestricted reuse, distribution, and reproduction in any medium, provided the original work is properly cited.

(Received 31 January 2021; Revised 16 Mach 2021; Accepted 30 June 2021) 
For children with IDD dependence on caregivers, whether professional or family, becomes essential. Caregivers have to perform basic tasks of feeding, bathing, medication, as well as duties of providing emotional support and company, and teaching. Majority of children with disabilities (75\%) do not attend regular schools (3). They are largely dependent on such caregivers, and special educational training institutes or educators. It becomes important to maintain a routine in the daily lives of children with IDD to relieve stress, to allow the child to make sense of her/his surroundings and learn new things.

The World Health Organisation declared coronavirus a Public Health Emergency of International Concern (PHEIC) on 30th January, 2020. It released guidelines for countries for rapid response to the virus and management of the health sector and resource management. Preventive measures include wearing masks, regular washing of hands, physical distancing of at least 1 meter and social isolation. The pandemic caused curfews and stay at home orders in most countries. By the third week of January 202193.8 million cases of coronavirus have been reported worldwide, along with 2.01 million deaths. In India, the lockdown and the pandemic has taken a toll on the majority of the population. With over 10.5 million cases of infections recorded, India also showed a rising rate of unemployment, leaving the people not only susceptible to the virus but also to unemployment, homelessness, and hunger $(4,5)$.

Corporations have provided the necessary telecommuter services to allow their employees to work from home and maintain social isolation. However, such an instant change has been taken in a mixed manner by disability rights activists and PWDs, who have for decades fought for remote work. Although the new form of virtual living has opened up some doors for people with disabilities, as they can now attend meetings, take up courses, participate in social and cultural events, the information provided in online platforms is textual, and not disable friendly. There is a lack of content in Indian sign language for the $\mathrm{HoH}$ population, and there is an absence of audio clips, making information inaccessible for the visually impaired. The pandemic has also increased the inaccessibility of healthcare and employment for those who are disabled and struggling to make ends meet (6-9).

According to a report by the National Centre for the Promotion of Employment for Disabled Persons (NCPEDP)—which includes results from a study of 1,067 people with disabilities (about $73 \%$ male, $27 \%$ female)-over $73 \%$ of those surveyed experienced serious difficulties due to the lockdown. [...] Living with disabilities has been more of a task post-lockdown because of governmental negligence, combined with inaccessibility to healthcare and rewarding employment. A large class divide has become increasingly visible in the lockdown. (The Hindu, 2020)

In such a worldwide health crisis, a review of international and national laws and policies needs to be made. Article 11 of the UN Convention on Rights of Persons with Disabilities (CRPD) 2006 states that States shall take all necessary measures to ensure protection and safety of PWDs in humanitarian emergencies, armed conflict and natural disasters. Article 21 elaborates that information, be it official information, news or internet based, should be made accessible to PWDs in all formats, for example in braille, sign language, and alternative communication modes. Article 25 declares that "States Parties recognize that persons with disabilities have the right to the enjoyment of the highest attainable standard of health without discrimination on the basis of disability[...] Provide persons with disabilities with the same range, quality and standard of free or affordable health care and programmes as provided to other persons.[...] Prevent discriminatory denial of health care or health services or food and fluids on the basis of disability" (10).

India, a ratifying party state, implemented the Rights of Persons with Disabilities (RPWD) Act in 2016. Section II of the RPWD Act 2016 states that "The persons with disabilities shall have equal protection and safety in situations of risk, armed conflict, humanitarian emergencies and natural disasters." Section V states that the government will develop schemes and programmes in order to safeguard and promote the standards of living and health conditions of PWDs. It will provide community centers with good living conditions, 
including sanitation, safety, healthcare and counselling; support during armed conflicts, manmade or natural disasters; unemployment allowance and care-giver allowance for those with special needs; barrier free-access to healthcare institutions and Government and private hospitals, and provide aids, appliances, medicines and healthcare services free of cost to those PWDs with low income (11).

Section 8 of the Rights of Persons with Disabilities Act, 2016 guarantees equal protection and safety for persons with disabilities in these situations. It also mandates Disaster Management Authorities at District/State/National levels to take measures to include persons with disabilities in disaster management activities and to keep them duly informed about these. These authorities are mandatorily required to involve the concerned State Commissioner for Persons with Disabilities during disaster management. (Comprehensive Disability Inclusive Guidelines for protection and safety of persons with disabilities (Divyangjan) during COVID 19, 2020. pp 2)

The Government of India has declared the situation of Covid-19 pandemic as a national disaster under the National Disaster Management Act (2005). The Act was to enable an effective management of disasters at the Centre level It also provides for State and district level authorities to plan for implementation of national plans (12). The Central Government in March introduced the "Comprehensive Disability Inclusive Guidelines For Protection and Safety of Persons With Disabilities (Divyangjan) during COVID 19" (guidelines), which will be discussed later. The guidelines state that all information is to be made available in accessible formats, and training pertaining to different kinds of disabilities are to be given to health workers and officials (13).

The intellectually disabled community is one of the groups which have faced adverse impacts due to the lockdown, by not only being more vulnerable to the disease because of comorbidities, and health issues, but also because of the aggravated decline in accessibility to essential services and facilities. This paper focuses on the changes that Covid 19 has brought to the lives of child athletes with IDD in the area of West Bengal. The objectives of the study are as follows:

1. To assess the impact of Covid 19 on athletes with intellectual disabilities on their daily lives.

2. To observe the lack of accessibility, if any, to healthcare services.

3. To assess, if possible, how athletes with intellectual disabilities manage through Covid 19 restrictions.

4. To study the Government response during the pandemic for athletes with disabilities.

\section{METHODOLOGY}

The respondents of our study included parents of child athletes with IDD, as it was difficult communicating with the children themselves. The athletes belonged to the age group of 10-16 years. The age of their diagnosis was early starting from the time of birth till 5 years of age, with the diagnosis comprising a range of intellectual and developmental disabilities. The respondents' children do not suffer from any comorbidities. A more detailed description has been presented in the Table 1.

Semi Structured questionnaires were used in personal interviews over telephone with the caregiver/parent of the primary respondents. Recorded verbal consent was used. The interviews were transcribed, translated and reconfirmed from the respondents. Narrative analysis of Qualitative methodology was used for evaluation of the content. The study was evaluated by the Civilian Welfare Foundation.

\section{RESULTS AND DISCUSSION}

In this section we have tried to assess the impact of the pandemic and the consequent lockdowns on our respondents, and the changes that it has brought about in patterns of behavior, sleep, and emotions as a result of breakdown of routine everyday life. We have then analyzed the problems of accessibility of healthcare services during the pandemic using other empirical research, along with the data collected from our respondents. The ways of managing changes, and the stress associated with it by our respondents' children have been studied, focusing on sports as one of the important mechanisms employed. Finally, we have looked at the 
government response and their implementations

conversations with our respondents. drawing from secondary data sources and

Table 1: Demographics of the respondents

\begin{tabular}{|c|c|c|c|c|c|c|}
\hline Respondent & $\begin{array}{l}\text { Age of } \\
\text { Child }\end{array}$ & $\begin{array}{l}\text { Sex of } \\
\text { Child }\end{array}$ & $\begin{array}{c}\text { Age of } \\
\text { Diagnosis }\end{array}$ & Details of Diagnosis & $\begin{array}{c}\text { Sport/Game } \\
\text { played }\end{array}$ & Comorbidity \\
\hline 1 & 16 & female & 5 years & $\begin{array}{l}\text { rickets, speech disability, problem } \\
\text { with identifying people, intellectual } \\
\text { disability }\end{array}$ & $\begin{array}{l}\text { Special } \\
\text { olympics }\end{array}$ & No \\
\hline 2 & 11 & female & 3 years & $\begin{array}{l}\text { speech disability, intellectual } \\
\text { disability, lack of bodily control }\end{array}$ & $\begin{array}{l}\text { hockey, } \\
\text { throwball, } \\
\text { sprinting }\end{array}$ & No \\
\hline 3 & 12 & male & 3 years & global developmental delay, speech & $\begin{array}{l}\text { special } \\
\text { olympics }\end{array}$ & No \\
\hline 4 & 15 & male & $\begin{array}{l}\text { after } 2 \\
\text { years }\end{array}$ & autism & swimming & No \\
\hline 5 & 11 & male & $\begin{array}{c}\text { from } \\
\text { beginning }\end{array}$ & down syndrome, speech disability & $\begin{array}{l}\text { dance, special } \\
\text { olympics }\end{array}$ & No \\
\hline 6 & 15 & female & $\begin{array}{l}6 \text { months } \\
\text { to } 1 \text { year }\end{array}$ & cerebral palsy, physical disability & $\begin{array}{l}\text { throwball, } \\
\text { track, }\end{array}$ & No \\
\hline 7 & 10 & male & 2 years & $\begin{array}{c}\text { intellectual disability and hard of } \\
\text { hearing }\end{array}$ & $\begin{array}{l}\text { football, } \\
\text { cricket }\end{array}$ & No \\
\hline 8 & 16 & male & $\begin{array}{l}\text { from the } \\
\text { beginning }\end{array}$ & $\begin{array}{l}\text { slow learning disability, and physical } \\
\text { disability }\end{array}$ & $\begin{array}{l}\text { football, } \\
\text { athletics, track }\end{array}$ & No \\
\hline 9 & 10 & male & $2+$ years & autism & $\begin{array}{c}\text { football, } \\
\text { dance }\end{array}$ & No \\
\hline 10 & 14 & female & 3 years & Autism and mental retardation & $\begin{array}{c}\text { dance, } \\
\text { swimming }\end{array}$ & No \\
\hline
\end{tabular}

\section{Impact of Pandemic on IDD Athletes}

$15 \%$ of the world's population lives with a form of disability (14). The disabled community is one of the groups which have been severely hit with the pandemic, and the consequent lockdowns. Many PWDs are dependent on their caregivers, and access to medical and rehabilitation centers which is hindered by the practice of social isolation and social distancing. Professional caregivers are unable to visit their patients. Persons with intellectual disabilities cannot be expected to maintain social isolation, as they are dependent on caregivers, be it their family or professional caregivers (14-16).

Persons with disabilities are also one of the most vulnerable groups susceptible to the virus (17).
Adults with disabilities are three times more likely to have heart disease, stroke, diabetes, or cancer than adults without disabilities (18). People with IDD are more likely to die from covid-19 due to high comorbidity with pre-existing conditions such as hypertension, heart disease, respiratory disease, and diabetes which are identified as risk factors for poor outcomes from COVID-19. They have higher risk of influenza and pneumonia, and higher and premature risk of death (19-21).

[...]the lockdown measures have meant that for a prolonged period, people with IDD have stopped working and participating in their communities, centers and services, and have had their routines interrupted [...] it has been difficult to understand 
the situation surrounding COVID-19 and selfregulate their behavior, particularly for those with extensive support needs. (Navas et al. 2020, pp 5)

All of the respondents have reported that their children wear masks when they go out, and use sanitizers when instructed. Initially there was a gap in grasping why they had to do so, but now they have become habituated to it. Out of ten, four respondents stated that their child does wear the mask when they go out, but they have difficulty in wearing it for prolonged time, and are often unwilling to cover their nose because of suffocation.

Pandemic has also given rise to psychological stress, and persons with IDD are more likely to be vulnerable to it (22). Individuals with IDD may suffer more from mental health deterioration due to Covid-19 and lockdown restrictions, inability to access services, fear and anxiety that accompanies the pandemic, and is also a result of the wide media reportage. The pandemic has also brought about changes in behavioural patterns, which becomes especially difficult for those with IDD who use routine to make sense and control their surroundings, and maintain emotional wellbeing $(19,20,23,24)$. Children with disabilities are more likely to be irritable, distracted, face loss of concentration and feel discomfort (24). Nonmedication based strategies such as accessing communities are absent which might lead to irritation and changes in patterns of behaviour among individuals with IDD. As a result, they might be victims of abuse during the pandemic due to lack of community support (20).

All of the respondents reported that their wards have met people during the pandemic occasionally, either relatives or friends. Therefore these children with IDD were not in isolation, and the brunt of the pandemic did not hit them as hard, as they were surrounded by family members, and also met few relatives and friends. 3 of the respondents reported that their children wanted to go out, but also got irritated and suffocated and wanted to come back home early. The shakiness in going out can be seen as resulting from a sudden shift from their newly acquired organisation and comfort space of their home. Despite initially wanting to go out, the children now have adjusted and established certain routines and patterns of behaviour, which when going out disrupts the said patterns and routines. Children with IDD require stable routines for better functioning and understanding of the situation, any little disruption can cause behavioural changes. They faced problems when the lockdown was announced, as they now had to break away from their old patterns of going to school, going to play, engaging and interacting with others. In the lockdown, staying at home, they have built a new set of rules and routine, which again is getting disrupted when they go out once in a while.

Respondent 4 says that her son "[...] was inside the house for a very long time due to Covid19 , but once due to a medical emergency we had to take him out and that day he reacted in a very difficult and different way so much so that it almost became impossible for us to control him. It was basically the effect of staying indoors for the longest time." 8 of the respondents have reported changes in sleeping patterns of their children during the lockdown. One of the reasons attributed to such a change was the breakdown of routine. Once their daily routine had changed, their sleep pattern altered. The children were sleeping later than usual, and waking up later than usual. Along with disruptions in sleeping patterns, there were mental and behavioural changes as well. 8 of the respondents have reported a wide range of emotions that their children are facing: stress, anxiety, anger, irritation, suffocation and aggression. All these were perceived to be resulting from being stuck and confined to the household. The discontinuation of the activities they engaged in, which helped them manage their emotions could be seen as the primary reason. The children were missing their schools, friends, and feeling isolated.

Role of parents raising children with IDD has expanded in the pandemic. It now includes being a social skills coach, special educator, speech pathologist, and mental and behavioural therapist. Often with little to no help from professionals $(19,24)$. Parents expressed facing challenges in the decreased levels of services now available for their children, and were worried that their children would fall further behind in education (23-24). Asbury et al. in How is COVID-19 Affecting the Mental Health of Children with Special Educational Needs and Disabilities and Their Families? (2020) reports that 
families with children with special educational needs have faced more mental health problems including anxiety, fear, low mood, and stress. The level of stress, anxiety, fear and loss expressed by the children and their families are more than the general population. Parents worry about their child with special needs concerning their future and educational needs, as most of their school activities have been stopped because of the pandemic. Loss was characterised by loss of networks of support, loss of routine, loss of inputs from specialists and financial loss. A loss of networks and specialised inputs, and routine have led to more challenging behaviour from the children, which parents find difficult to cope with. The parents report that since the closing of educational centers, there has been no tailored effort to help them with the losses incurred. Children displayed low moods, behaviour change and were acting out. "Parents described situations in which a child's low level of understanding led to distress because they could not understand why everything had changed." (pp 8). 5 of them reported that their children's routine had changed, primarily because schools were closed during the lockdown, and had caused a breakdown in their everyday routines. 6 of them have attended online webinars, most of which were organized by their children's schools. Many of the respondents were worried about their children's futures, as they felt they were lagging behind in school work. Parents now had to look after their children throughout the day. Earlier, because of school and sports, the parents could find some time for themselves. Instead now, they have to spend their entire day looking after their children and tending to their special needs.

Out of the 10 respondents, 4 have stated that their children have had online classes organised by the schools. However, two of them have reported that they had to stop the online classes as the children were not being able to concentrate and were increasing their anxieties. Respondent 4 reported "my son is not being able to concentrate in class, as he is not feeling important in class. In normal scenarios, special and privileged attention was given to him. I also have started feeling frustrated as there has been no progress or help. Rather there's been a regression in his abilities, he is no longer able to carry out the things he could earlier. I feel online classes are not fruitful, plus I don't know whether we can continue paying fees. I benefitted when he went to school as I got some time for myself." Respondent 6, on being asked about the impact of online classes on her child, says "Initially she attended her online classes but due to increased anxiety in this pandemic situation, she had to put that on hold".Two respondents have added that their children do not have online classes because they study in government schools. Moreover, because of the lack of smartphones and computers they were unable to take part in the classes. One of the parents stated that she brings the schoolwork back home, and after her daughter finishes the work, she again goes back to the school to submit it.

The child athletes with IDD have gone through behavioural and routine changes, marked by periods of emotional upheavals. Online classes and webinars have not been particularly helpful, as they cannot fully concentrate or comprehend the occurings in the class. Instead of helping, it has led to deterioration in many cases.

\section{Accessibility to Healthcare Services}

Improving health outcomes in a pandemic requires communication of information and preventive measures, identification of symptoms and recommendation of treatment. Persons with disabilities have suffered gravely in this aspect (1718). Information visually represented through graphs and charts are inaccessible to visually impaired persons and persons with intellectual disabilities. Public transportation facilities being restricted in the pandemic, has acted as a barrier to seek treatment and medical aid for PWDs. Facility of telehealth services is also challenging for people with visual impairment, hard of hearing, intellectual, physical or speech- related disabilities, and psychiatric patients who are often stigmatized in their home environment (18). The pandemic has also posed a challenge in gaining access to information, testing and treatment, which is usually taken care of by the mental health care professionals and caregivers. The absence of such professionals can affect infection rates, and physical and psychological well-being (22).

Three of the respondents reported having difficulty in accessing healthcare professionals. One 
of these three reported that besides having difficulty in access to doctors, she was having problems in finding affordable therapy for her son. Therapy is extremely costly, and rarely brings positive changes for her son. Four of the respondents reported that they were in contact with their family doctors during the pandemic. The other three reported that they did not need to visit the doctor.

Rationing of medical resources becomes an essential area of discussion to understand whether and how disability perspectives are included in such decisions. Decisions should be made on objective evidence on survival of Covid-19 virus, rather than on subjective decisions on "perceived quality of life associated with disability" (Sabatello, 2020. pp 3). Boyle et al. in The Public Health Response to the COVID-19 Pandemic for People with Disabilities (2020) argues that PWDs have a disadvantage in receiving healthcare in emergency situations. They are wrongly assumed to have a lower quality of life, and thus are prevented from accessing medical resources due to rationing.

To prevent discrimination, health care facilities should explicitly distinguish between disability status (e.g., deafness and intellectual disability) and comorbidities that have been shown to affect survival (e.g., end-stage cancer) as a criterion for denying lifesaving treatment of COVID-19. [...]Transparency in rationing decisions is essential for maintaining public trust in the medical response to this pandemic, particularly given the history of disability discrimination, including the connection between eugenics and the medical profession. (Sabatello, 2020.pp 3)

Apart from shortage of medical resources, PWDs are also facing problems in treatment. Due to fear of contagion, many visually impaired or hard of hearing patients are not able to take the help of interpreters, causing a restriction in communication. Persons with intellectual disability who need support of caregivers and family members, are being removed from such a support system in a hospital setting because of fear of infection.

In response to the above statement, it must be mentioned that our respondents' children stay with the family, and therefore haven't been removed from the primary support system of the family.
There has, however, been a loss of a secondary support system of companions, therapists, and classmates. All of the respondents reported that their children have always faced discrimination, but there has been no cases of excessive or special discrimination because of the lockdown. However Respondent 7 stated that "In the fear of discrimination specially in this pandemic situation, we try to keep him indoors as much as possible". On the other hand, one of the respondents stated that the lockdown has been empowering for selfindependence.

\section{Managing the Covid-19 life}

As athletes, the respondents' children regularly engaged in sporting activities and had access to playing grounds. However, due to the lockdown, the respondents' children were unable to engage in any sporting activities. All of the respondents reported that they had no access to sports grounds and activities. One reported that they were afraid to take their child outside because she is physically weak and suffers from cerebral palsy. Respondent 3 reported that "Due to the pandemic all his special Olympics classes are put on hold indefinitely." Similarly, Respondent 2 reported that, "For the last 7 months there had been no sports activities and he stayed indoors completely."

On the other hand, many of the respondents did engage in playing and exercising at home. Out of 10 respondents, 6 have responded that their child engages in home play either by following instructions from online classes, or by playing with friends and siblings. 5 respondents have answered negatively, whereas the other 5 have affirmed that their child continues exercising at home. Two of them have mentioned that their child participates in movement therapy which allows them to gain more flexibility in the body. Other than improving physical well-being, exercise and playing helps in mental well-being, and in establishing some sort of a routine in the pandemic.

Parents reported a range of coping skills, the most common being implementing behavioural strategies (e.g. reinforcement systems) and routines as well as engaging in enjoyable activities with the family (e.g. family games, walks outside). Parents also reported practicing 
meditation, exercising and eating healthy, providing space for family members to decompress and taking breaks from each other and connecting with other people, usually by phone or computer, to be helpful during the stay-at-home order. (Neece et al. 2020, pp 74344)

Besides taking part in games, two of our respondents have also taken part in relief work during the pandemic. One of them helped monetarily, and the other helped his father distribute ration among his neighbours. Another respondent reported that she had received aid from a few non-governmental organisations.

Here one of the strategies that the children with IDD uses to grapple with the lockdown is playing and taking part in special olympics events. With the lockdown being lifted, playing fields and clubs are slowly starting to open. What is noteworthy is the importance and the role sports have played in the lives of these children, and their individual reasons for continuing to play.

\section{Why Sports Matters}

Sports can be viewed as an egalitarian platform which helps manage social inequalities and discrepancies. It provides opportunities to the marginalised or disadvantaged section of the population. It also has the ability to inspire, motivate, and generate communitarian ties. Sports, apart from enhancing one's physical and mental development and well-being, also have the potential to improve one's confidence, self-perception and enlarge one's social circle (25-27).

Disability sports acts as a medium ensuring individuals to take charge of one's personal and environmental resources to gain capacities, from which one is usually deprived of due to one's disabilities. It allows the participants to gain a sense of achievement which helps heighten one's selfworth, and esteem allowing the athlete with disability to engage in processes of decision making and being in charge of her/his life. Sharing common facilities and services gives rise to a feeling of belongingness and inclusivity (25-28).

A sports programme for children and adults with IDD is vital to improve their eye-to-hand coordination, fitness, and confidence[...]Each skill is planned to improve their daily life skills such as walking, balance, cognitive and communication. The sports programmes also help in developing their fitness as well as confidence. Many sports activities are conducted as part of therapy (The CSR Journal, 2020)

8 of the respondents have stated that sports have benefited their children. One of the major benefits mentioned was their child had found companionship among fellow players, and had an engagement with a meaningful activity, and liked activities linked to sports or rather going to play, which included travelling and going out. Participating in sports gave them a stable routine. Two of them reported that sports have increased their children's flexibility and agility, and that they can now run faster. Two of the respondents on the other hand, have mentioned how the routine and engagement that is offered by sports which was beneficial before the lockdown, has now turned into a nuisance. Their children are not being able to cope with the sudden stop in their sporting activities.

Harada and Siperstein in The Sport Experience of Athletes With Intellectual Disabilities: A National Survey of Special Olympics Athletes and Their Families (2009) reports that athletes take part in Special Olympics to build friendships, and for social enjoyment. Motives of "fun and friendship" tend to drive such athletes into taking part in events more often than factors of external influence by others, and to bring about a sense of achievement. They also point out that "the results of the current study suggest that athletes with ID are just as likely to leave sports because they no longer have access to sport programs due to events outside the control of the athlete with ID" (pp 81), thus indicating that sports, aside from special olympics, or paralympics, is not disable friendly and inaccessible (29).

\section{Government Response for Persons with Disabilities}

In March, the Central Government introduced the "Comprehensive Disability Inclusive Guidelines For Protection and Safety of Persons With Disabilities (Divyangjan) during COVID 19" (guidelines). It states that all information regarding the virus, precautions, treatment and services are to be made available in accessible formats and websites. Persons 
responsible for handling emergency services should be trained on disability impairments, as well the rights of persons with disabilities. PWDs are to be given priority in treatment and online counselling sessions should be developed to de-stress PWDs and their families and manage the anxiety better. The Government assures that caregivers are provided with protective equipment to allow continuation of support services (12).

[...] essential support services, personal assistance, and physical and communication accessibility should be ensured e.g. blind persons, persons with intellectual/ mental disability (psycho-social) are dependent on caregiver support.[...] Caregivers of persons with disabilities should be allowed to reach Persons with disabilities by exempting them from restrictions during lockdown or providing passes in a simplified manner on priority (Comprehensive Disability Inclusive Guidelines for protection and safety of persons with disabilities (Divyangjan) during COVID 19, 2020. pp 3).

The Centre has promised to provide for three month's pension in advance to persons with disabilities, senior citizens, and widows under the National Social Assistance Programme. The Government will also provide an ex-gratia amount of 1000 for three months to the disabled community (30).

However, such a meagre amount will only be available to those who have a disability certificate, which many PWDs in India do not possess and thus cannot avail government schemes and services. Moreover, apart from exempting caregivers of lockdown restrictions, the government has failed to implement the above mentioned guidelines. The information on awareness about the pandemic present in their official site is unavailable in accessible formats.

The guidelines do not address the educational needs of the children with disabilities. No provisions and directions are laid out for distance, online or home based education. The pandemic has caused inaccessibility to special educators (30). Despite having various online elearning platforms in India, such platforms are not accessible to CWD. The Central Institute of
Educational Training (CIET) has facilitated accessibility in school curriculum for CWDs by providing reading series and audio books. However, there are no clear cut instructions on how such technologies are to be deployed to benefit CWDs in the pandemic (31-32).

All of the respondents answered that they had not received any government support during the pandemic. Two of them mentioned that they were unaware of any such governmental programme which offered them help. The others stated that they were not even receiving the 1000/- rupees that the government had promised. One of them stated that government aid does come, but is delayed, and they receive it once in two or three months. Respondent 2 stated, "There has been no help from the government, I have submitted the Mano Bikas form but there are absolutely no responses. I checked it so many times, in fact yesterday I travelled all the way to their office and yet nothing fruitful happened [...] I wish the government did something about her education, especially during this time financially. Since we don't have a smart phone both her education and therapy are getting hampered."

Respondent 7 also says, "At the beginning of the pandemic we heard about the policies of the government implemented for these children, but we didn't receive any help[...]This pandemic situation has made things worse, we couldn't pay the rent of our house for 28 months, it scares us so much because he is completely dependent on us. He needs extra care and financial help which is becoming very difficult for us to give him now. We belong to the working class and our work has been suspended for a long time and hence we can't give enough support to our child financially." All of the respondents stated that the government has not taken any steps to enable a better adjustment of children with IDD in the pandemic. They suggested a number of steps on several fronts. First, they reported that the aid of 1000 they receive monthly, (or are supposed to as it gets delayed) is not enough in this day and age. It does not cover their medical bills, rations, and other basic necessities. Second, they stated that the added therapy or equipment that their children require are too expensive. The government needs to make provisions for free or affordable therapy and medical treatment for children, rather than people with 
disabilities. Third, the government needs to not only be disable friendly, but also spread awareness amongst people, especially in a difficult time like the pandemic. Another aspect that was brought in was help regarding school fees and online classes. Many of the respondents reported that they were unable to fill the fees, and some of them lacked the technologies required for their children to continue their online classes.

\section{CONCLUSION}

The pandemic and consequent lockdowns have brought about a number of changes in the lives of the athletes with IDD. Persons with IDD make use of routines to make sense of their daily lives, and maintain order and control of their surroundings. With the breakdown of their daily routines, the respondents have reported a vast number of behavioural and emotional changes (fear, anxiety, irritation, restlessness, suffocation and anger), and changes in the sleeping patterns of their children. Activities of going to school or engaging in special olympics have been put on hold, which has resulted in these behavioural changes. Online webinars or classes have not helped the respondents' children. Instead some of them have reported it causing further damage, and deterioration. Through sports, these children not only had a stable routine and source of exercise, but also allowed them to gain companionship. However, the habit of playing sports or of going outside to participate in Special Olympics has come to a sudden halt, which has remained incomprehensible to many of our respondents, and has resulted in emotional upheavals.

In trying to manage the stress of the pandemic, most of our respondents try to engage their children in home play and exercise. Sports in the lives of the IDD athletes have played a central role in helping build networks and support systems, improving the children's agility, and all over wellbeing. In previous studies, it has been documented the role sports play in development of social capital and psychosocial development (25-26) .Engaging in active play, even if it is at home, has provided the athletes ways in managing stress and maintaining routine. Another activity that some of the respondents have engaged in is relief work. Participating in relief work increases one's sense of social responsibility, and like sports, helps build social networks and boost one's self worth and confidence. There is limited data, and a lack of systems to monitor the healthcare needs of persons with intellectual disabilities. Incorporating disability as a demographic identifier in infection rates helps in the creation of better mitigation strategies. Although intellectual disability forms a smaller portion of the disabled population, it is one of the groups which is increasingly affected by the virus (17). Data collection of infection, recovery and mortality rates among PWDs during and after this health emergency will help prepare for future pandemics, allowing for equitable healthcare allocations.

This paucity of data on COVID-19 trends among the IDD population further exposes the reality that there is no adequate surveillance structure in place to monitor COVID-19, or other public health outcomes, among the IDD population. This is even more disconcerting during this time in which populations with higher prevalence of identified co-morbidities, such as people with IDD, may be at increased risk of developing severe outcomes, including death, from COVID19 (Turk et al. 2020, pp 2)

People with IDD face a disadvantage when it comes to rationing of medical resources, as mentioned above. Decisions regarding rationing should be made on objective standards rather than on biases. Additionally, health services need to be made more accessible to persons with disabilities. In the pandemic situation, restrictions in transportation facilities have resulted in many patients not being able to visit their doctors and/or therapists on a regular basis. They have been cut off from necessary medical services and facilities. Telehealth services do not work for Persons with IDD, as well as other forms of disability, since it is difficult for them to explain through the web the problems they are facing. The lockdown, and measures of social distancing has also resulted in loss of contact and support from caregivers and support systems. In such a scenario, measures should be taken to allow health professionals and caregivers to visit their patients on a regular basis, so as to not let their patients' conditions deteriorate. Medicine and therapeutic equipment needs to be made available to the individuals through door to door services. Modes 
of communication, if they have to be conducted through online portals, need to be made disablefriendly, with the inclusion of audio and visual aids. Few of the respondents have reported that therapy and the equipment necessary for their children were too expensive for them, and sometimes did not result in positive changes. In light of these statements, therapy should not only be made more accessible financially, but tailored to fit the needs of particular patients in attempting to bring about improvement and positive changes.

The government needs to take an active step in helping persons with disabilities in the pandemic. The ex-gratia amount in this day and age is too little to fulfill the basic needs of people, which has been reiterated by our respondents. The amount needs to be increased keeping in mind the requirements of PWDs, in addition to issuing the entire population of PWDs with a disability certificate so that they can access the governmental schemes and benefits. Therapy and medical services need to be made affordable or free to a larger population, in order to allow the PWDs to lead a life of dignity and wellbeing. In the pandemic situation, transportation services and medical services need to be made available on a regular basis, and at a minimum cost. Information regarding the pandemic must be updated on a regular basis and be made available in accessible formats in government portals using audio and visual aids. Additionally, attention must also be paid to the educational needs of children with disabilities. Online learning is not suitable for all groups of PWDs. Moreover, many cannot afford the equipment (computers, laptops or smartphones) and services (internet) which are required for elearning. In such a situation, the government needs to extend their help in either making these very equipment and services affordable, or making sure that all students with disabilities have equal access to educational curriculum.

A joint effort needs to be made by the government, doctors and therapists, and nongovernmental organisations to bring about a necessary holistic change in the functioning of systems and services. The pandemic has made apparent the already existing differences and differential treatment meted out to persons with disabilities. Change must be brought through awareness and education, along with enforcement of rights and privileges of persons with disabilities.

\section{ACKNOWLEDGEMENT}

Thank you to all parties involved in this research so that it is carried out properly. Special thanks to lpdp scholarship for research financing. Alas Purwo National Park Hall and the community around the buffer village.

\section{CONFLICT OF INTEREST}

There is no conflict of interest in this present research paper. This research work is not a part of any other studies and it is our original work.

\section{REFERENCES}

1. Definition of Intellectual Disability. (n.d.). American Association of Intellectual and Developmental Disability. Retrieved November 28, 2020, from https://www.aaidd.org/intellectual-

disability/definition

2. Intellectual and Developmental Disabilities (IDDs): Condition Information. https://Www.Nichd.Nih.Gov/. Retrieved November 28, 2020

from https://www.nichd.nih.gov/health/topics/idds/conditi oninfo/default\#: :text=Intellectual $\% 20$ and $\% 20$ develop mental\%20disabilities\%20(IDDs)\%20are\%20disorders $\% 20$ that $\% 20$ are $\% 20$ usually,multiple $\% 20$ body\%20part s\%20or\%20systems

3. Pooja Pandey and Sumyesh Srivastava. Excluding the excluded: India's response to the education of children with disabilities during Covid-19. Times of India. 2020, April https://timesofindia.indiatimes.com/blogs/voices/excl uding-the-excluded-indias-response-to-the-educationof-children-with-disabilities-during-covid-19/

4. World Health Organization. Country and Technical Guidelines: Coronavirus Disease (Covid 19). Retrieved November 28, 2020, from https://www.who.int/emergencies/diseases/novelcoronavirus-2019/technical-guidance

5. "Coronavirus (COVID-19) - Google News." Google News. Retrieved January 24, 2021 (https://news.google.com/covid19/map?hl=enIN\&mid=\%2Fm\%2F03rk0\&gl=IN\&ceid=IN\%3Aen).

6. Campoamor, D. Disabled People React to Coronavirus Work From Home Accommodations. Teen Vogue. 2020, March 24. https://www.teenvogue.com/story/disabledpeople-react-to-coronavirus-work-from-homeaccommodations

7. Jagannathan, M. 'I was told I could never work remotely': Before coronavirus, workers with disabilities say they implored employers to allow them to work from home. MarketWatch. 2020, May 5 https://www.marketwatch.com/story/theres-noexcuse-for-not-offering-remote-work-the-coronavirusinduced-work-from-home-revolution-feels-like- 
vindication-for-some-workers-with-disabilities-202005-01

8. Ryan, F. Covid lockdown opening up world for people with disabilities. The Guardian. 2020, April 20 https://www.theguardian.com/world/2020/apr/20/co vid-lockdown-opening-up-world-for-people-withdisabilities

9. Suchitra. Coronavirus lockdown. The Hindu. 2020, June 14. https://www.thehindu.com/news/national/coronav irus-lockdown-in-the-pandemic-the-disabled-remainan-invisible-

minority/article31828510.ece\#: :text=For\%20many\% 20like $\% 20$ Pulinder\%20and,increasingly $\% 20$ visible $\% 20$ in $\% 20$ the $\% 20$ lockdown.

10. United Nations. Convention on the Rights of People with Disabilities. 2006, December 6 https://www.un.org/disabilities/documents/conventio n/convention_accessible_pdf.pdf

11. The Rights of Persons With Disabilities Act, 2016. https://www.ncpedp.org/sites/all/themes/marinelli/d ocuments/Rights\%20of\%20Persons $\% 20$ with\%20Disab ilities\%20(RPWD)\%20Act\%202016.pdf

12. Explained: Disaster Management Act, 2005. Lexlife India. 2020 , March 24. https://lexlife.in/2020/03/24/explained-disastermanagement-act-2005/

13. Comprehensive Disability Inclusive Guidelines for protection and safety of persons with disabilities (Divyangjan) during COVID 19, 2020. http://disabilityaffairs.gov.in/content/page/whatsnew.php

14. Roy B. Mehrotra S. Covid-19: Implications for the disabled. The Hindu Business Line. 2020, April 03. https://www.thehindubusinessline.com/opinion/covid19-implications-for-the-disabled/article31250730.ece

15. Amrita Aurora. Restricted Access To Care In Lockdown Puts People with Disabilities At Risk. Youth Ki Awaaz. 2020, June 16. https://www.youthkiawaaz.com/2020/06/impact-ofcovid-19-on-persons-with-disabilities-the-largestinvisible-minorities-of-indi/

16. Srinidhi Raghavan. For the disabled community, strained access to information and help in lockdown severely disrupts life. Firstpost. 2020, April 23. https://www.firstpost.com/living/for-the-disabledcommunity-strained-access-to-information-and-help-inlockdown-severely-disrupts-life-8276081.html

17. Boyle CA, Fox MH, Havercamp SM, Zubler J. The public health response to the COVID-19 pandemic for people with disabilities. Disability and Health Journal. 2020; 13(3):100943.

18. Sabatello M, Burke TB, McDonald KE, Appelbaum PS. Disability, Ethics, and Health Care in the COVID-19 Pandemic. American Journal of Public Health. 2020; 110(10):1523-1527.

19. Navas P, Amor AM, Crespo M, Wolowiec Z, Verdugo MÁ. Supports for People with Intellectual and Developmental Disabilities during the COVID-19 Pandemic from their Own Perspective. Research in Developmental Disabilities. 2021; 108:103813.
20. Tromans S, Kinney M, Chester V, Alexander R, Roy A, Sander JW, Dudson H, Shankar R. Priority concerns for people with intellectual and developmental disabilities during the COVID-19 pandemic. BJPsych Open. 2020; 6(6): 122.

21. Turk MA, Landes SD, Formica MK, Goss KD. Intellectual and developmental disability and COVID-19 case-fatality trends: TriNetX analysis. Disability and Health Journal. 2020; 13(3): 100942.

22. Gulati G, Fistein E, Dunne CP, Kelly BD, Murphy VE. People with intellectual disabilities and the COVID-19 pandemic. Irish Journal of Psychological Medicine. 2020; 38(2): 158-159.

23. Asbury K, Fox L, Deniz E, Code A, Toseeb U. How is COVID-19 Affecting the Mental Health of Children with Special Educational Needs and Disabilities and Their Families?. Journal of Autism and Developmental Disorders. 2021; 51: 1772-1780.

24. Neece C, McIntyre LL, Fenning R. Examining the impact of COVID-19 in ethnically diverse families with young children with intellectual and developmental disabilities. Journal of Intellectual Disability Research. 2020; 64:739-49.

25. Adhikary D, Brahmachary A, Kar A, Musaddi D, Moulik S. Sports and Social Capital: A Qualitative Study on Women Athletes with Disabilities. International Research Journal of Multidisciplinary Scope. 2020; 1(4): 1-12. https://doi.org/10.47857/irjms.2020.v01i04.014

26. Brahmachary A, Moulik S. Sports as a tool for Inclusion and as a model of empowerment for persons with disabilities. New Delhi : Adhyayan Publishers. 2018.

27. McConkey R. Sports and intellectual disability: a clash of cultures? Advances in Mental Health and Intellectual Disabilities. 2016; 10(5): 293-298.

28. Special Olympics Bharat. Sports as a Development Tool for People with Intellectual Disabilities - The CSR Journal. The CSR Journal. 2020, November 21. https://thecsrjournal.in/sports-people-withintellectual-disabilities-special-olympics-bharat/

29. Harada CM, Siperstein GN. The Sport Experience of Athletes with Intellectual Disabilities: A National Survey of Special Olympics Athletes and Their Families. Adapted Physical Activity Quarterly. 2009; 26(1): 68-85.

30. Nipun Malhotra. Disabled Indians can't be afterthought in Covid. Disability secys needed in all ministries. ThePrint. 2020, May 25. https://theprint.in/opinion/indias-disabled-cant-beafterthought-in-covid-crisis/428162/

31. Akhilesh Pandey. COVID-19: How government failed people with disabilities. 2020, October 2 . https://caravanmagazine.in/health/covid-19-exposesfailure-of-the-governments-accessible-india-campaign

32. Covid-19 and Rights of Persons with Disabilities in India. OHRH. 2020, May 11. https://ohrh.law.ox.ac.uk/covid-19-and-rights-ofpersons-with-disabilities-in-india/ 